\title{
In-situ permeability of fault zones estimated by hydraulic tests and continuous groundwater-pressure observations
}

\author{
Norio Matsumoto ${ }^{*}$ (1) and Norio Shigematsu
}

\begin{abstract}
In-situ permeability of the Median Tectonic Line (MTL) fault zone in Mie Prefecture, southwest Japan, was estimated using hydraulic tests and groundwater pressure observations in two boreholes. The screen depths in Holes 1 and 2 are located, respectively, in a major strand of the MTL fault zone within the Sambagawa metamorphic rocks and a branching fault developed in the hanging wall of the MTL within the Ryoke mylonite. The estimated permeability at Hole 1 ranges from $5.3 \times 10^{-17}$ to $5.0 \times 10^{-16} \mathrm{~m}^{2}$, and that at Hole 2 ranges from $4.4 \times 10^{-16}$ to $1.5 \times 10^{-15} \mathrm{~m}^{2}$. We also measured the permeability of the protolith close to the screened depth of Hole $1\left(3.4 \times 10^{-19}\right.$ and $\left.3.7 \times 10^{-19} \mathrm{~m}^{2}\right)$ and Hole $2\left(3.1 \times 10^{-19}\right.$ and $\left.6.2 \times 10^{-19} \mathrm{~m}^{2}\right)$. The permeability of the fault zone was found to be more than 100 and 700 times higher than the protolith permeability at Holes 1 and 2, respectively. The permeability data for Holes 1 and 2 are consistent with previously reported permeability data for samples from an MTL outcrop. The permeability observed in this study reflects the complex fault zone permeability structure of the MTL fault zone.
\end{abstract}

Keywords: Fault zone permeability, Slug test, Pumping test, Permeability of drillcore sample, Median Tectonic Line

\section{Introduction}

The permeability structure around fault zones plays an important role in fault hydrogeology and movement. The fault zone is described as a single or multiple high-strain core (fault core) surrounded by a fractured damage zone (Caine et al. 1996; Faulkner et al. 2010; Bense et al. 2013). A number of studies about laboratory measurements of permeability of natural and synthetic fault materials indicate low permeability within the fault core and variable permeability in the complex damage zone structure, which is governed by macroscale fracture networks and low-permeability deformation bands (e.g., Faulkner et al. 2010; Carpenter et al. 2014).

Several studies of bulk fault zone permeability have used borehole in-situ observations. Kitagawa et al. (1999, 2002, 2007) and Kitagawa and Kano (2016) showed that permeability in the branch fault of the Nojima Fault ranged

\footnotetext{
*Correspondence: n.matsumoto@aist.go.jp

Geological Survey of Japan, National Institute of Advanced Industrial Science and Technology (AIST), AIST Tsukuba Central 7, 1-1-1 Higashi, Tsukuba, Ibaraki 305-8567, Japan
}

from $1 \times 10^{-13}$ to $2 \times 10^{-13} \mathrm{~m}^{2}$ by repeatedly performing cross-hole water injections. Sutherland et al. (2012) reported about $10^{-14} \mathrm{~m}^{2}$ at $50 \mathrm{~m}$ above the principal slip zone using boreholes drilled through the Alpine Fault in New Zealand. Xue et al. (2013) described an average permeability value of $1.4 \times 10^{-15} \mathrm{~m}^{2}$ at $200-600 \mathrm{~m}$ below the principal slip zone of the Longmenshan Fault, China, using continuous groundwater-level measurement.

Meanwhile, Wibberley and Shimamoto (2003) reported laboratory-derived permeability data for the Median Tectonic Line (MTL) fault zone using samples from the Tsukide outcrop. Their permeability data show wide variation with fault rock microstructure, and central slip zone gouges have the lowest permeability.

The Geological Survey of Japan (GSJ), part of the National Institute of Advanced Industrial Science and Technology (AIST), has drilled three boreholes into the MTL at the Matsusaka-Iitaka (ITA) observatory about $15 \mathrm{~km}$ east of the Tsukide outcrop. We studied the fault zone permeability in two of these boreholes (Fig. 1) using hydraulic tests and groundwater pressure observations and also measured the permeability of drillcore samples 


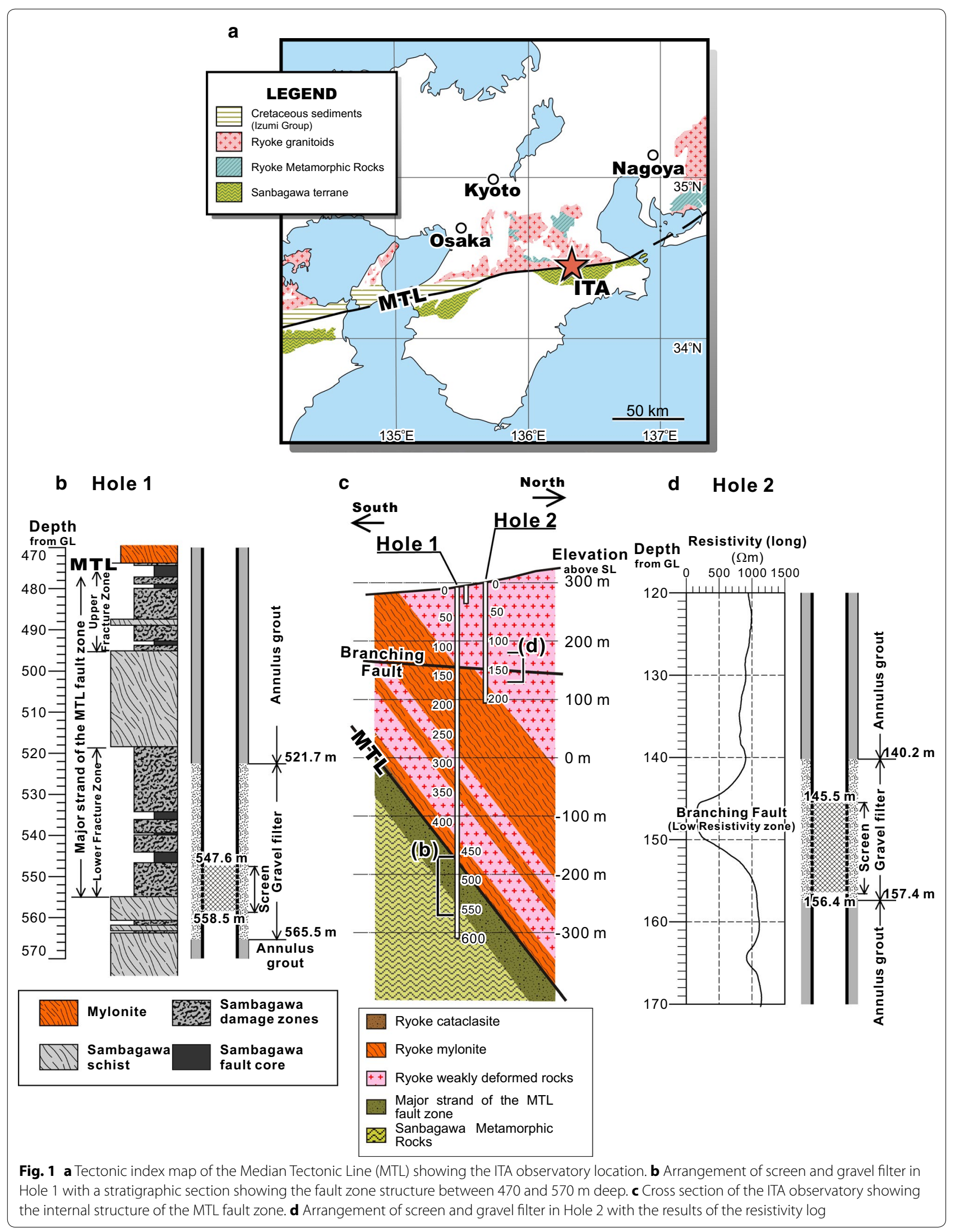


of protoliths. Our aim is to verify the complex permeability structure at the MTL showed by Wibberley and Shimamoto (2003) by using in-situ permeability data produced by hydraulic tests and long-term groundwater pressure observations.

\section{ITA observatory and lithology at screen depth}

ITA is an integrated groundwater observatory developed to predict Nankai Trough megathrust earthquakes (Itaba et al. 2010; Koizumi 2013). Holes 1 and 2 are 600.0 and $208.3 \mathrm{~m}$ deep, respectively, and Hole 1 encountered the MTL as a lithological boundary at $473.9 \mathrm{~m}$ (Shigematsu et al. 2012); see Table 1 and Fig. 1b-d for borehole dimensions and configurations. Shigematsu et al. (2012) described the detailed structure and lithology of drillcore samples from Hole 1. The boreholes were cased and annulus grouted. Screened casing and gravel filter pack were installed in each borehole (Fig. 1b, d). Since the borehole casing is fully grouted above and below the gravel filter pack, groundwater travels in and out of the borehole only through the gravel filter pack; the pack length is used in the analysis of the slug and pumping tests.

Figure 1c shows the ITA observatory cross sections. The MTL is oriented $\mathrm{N} 86^{\circ} \mathrm{E} 56^{\circ} \mathrm{N}$, the hanging wall above the MTL consists of Ryoke granitoids, and the rocks in the footwall derive from Sambagawa metamorphic rocks (Shigematsu et al. 2012). In the footwall immediately beneath the MTL, an approximately 40-m-thick zone of intensively fractured Sambagawa metamorphic rocks represents a major strand of the MTL fault zone. Along Hole 1, the Sambagawa metamorphic rocks are intensively fractured down to $555.0 \mathrm{~m}$, and this strand is divided into upper and lower fracture zones (at depths of 473.9-495.0 and 520.0-555.0 m, respectively) (Fig. 1b). Within the hanging wall of the MTL, several shallowly dipping branching faults of the MTL have developed. One of the more conspicuous of these faults is located at a depth of $138.5 \mathrm{~m}$ in Hole 1. The similarity of the resistivity logging data in Holes 1 and 2 (Shigematsu et al. 2012) and the attitude of the fault within the drillcore sample indicate that the branching fault located $138.5 \mathrm{~m}$ deep in Hole 1 can be correlated with the low-resistivity zone located $145 \mathrm{~m}$ deep in Hole 2.
The gravel filter pack in Hole 1 is $521.7-565.5 \mathrm{~m}$ deep (Fig. 1b). This depth interval allows Hole 1 to monitor the hydraulic properties of the lower fracture zone of the major strand of the MTL fault zone. The gravel filter pack in Hole 2 is 140.2-157.4 m deep (Fig. 1d), which intersects one of the shallowly dipping branching faults in the hanging wall.

\section{Permeability of protolith samples near the screened depths}

The permeability of four drillcore samples taken near the screened depths of Holes 1 and 2 was measured using the method in standard JIS A 1218 (Japanese Geotechnical Society 2015). The samples were taken from drillcore samples of Hole 1 at depths of 76.40-76.80, 125.60$125.90,564.20-564.50$, and $573.40-573.70 \mathrm{~m}$; we refer to these samples as Samples 1, 2, 3, and 4, respectively. Samples 1 and 2 are Ryoke-derived weakly deformed gabbro and granitic protomylonite corresponding to about 54 and $4 \mathrm{~m}$, respectively, above the depth of the gravel filter pack at Hole 2. Sample 3 is pelitic schist of the Sambagawa metamorphic rocks within the depth of gravel filter pack at Hole 1. Sample 4 is pelitic schist of the Sambagawa metamorphic rocks $8 \mathrm{~m}$ below the gravel filter pack at Hole 1 . Table 2 shows the specimen and permeability cylinder collar dimensions.

Hydraulic conductivity $K$ (length/time) was estimated by the following equation (Japanese Geotechnical Society 2015):

$$
K=\frac{L}{h} \frac{Q}{A\left(t_{2}-t_{1}\right)},
$$

where $L$ is length of the specimen, $Q$ is runoff volume, $h$ is difference of water level, $A$ is the specimen cross-sectional area, and $t_{2}-t_{1}$ is measurement time.

We performed five experiments for each drillcore sample, and Table 3 shows the results. We derived average permeabilities of $3.1 \times 10^{-19}, 6.2 \times 10^{-19}, 3.4 \times 10^{-19}$, and $3.7 \times 10^{-19} \mathrm{~m}^{2}$ for Samples 1, 2, 3, and 4, respectively.

\section{Hydraulic test methods \\ Slug test}

We applied the method of Bouwer and Rice (1976) and Bouwer (1989) to slug test data from Holes 1 and 2. Hydraulic conductivity $K$ was calculated by

Table 1 Locations and specifications for Holes 1 and 2 at the ITA observatory

\begin{tabular}{|c|c|c|c|c|c|c|c|c|}
\hline Hole & Latitude $\left({ }^{\circ}\right)$ & Longitude $\left({ }^{\circ}\right)$ & Altitude (m) & $\begin{array}{l}\text { Total } \\
\text { depth }(\mathrm{m})\end{array}$ & $\begin{array}{l}\text { Screened } \\
\text { depth }(\mathrm{m})\end{array}$ & $\begin{array}{l}\text { Depth of gravel } \\
\text { filter pack out- } \\
\text { side casing (m) }\end{array}$ & $\begin{array}{l}\text { Diameter } \\
\text { of casing }(\mathrm{m})\end{array}$ & $\begin{array}{l}\text { Borehole diameter } \\
\text { at the screened } \\
\text { depth }(\mathrm{m})\end{array}$ \\
\hline 1 & 34.4530 & 136.3129 & 295.56 & 600.0 & $547.6-558.5$ & $521.7-565.5$ & 0.151 & 0.270 \\
\hline 2 & 34.4534 & 136.3129 & 300.74 & 208.3 & $145.5-156.4$ & $140.2-157.4$ & 0.151 & 0.270 \\
\hline
\end{tabular}




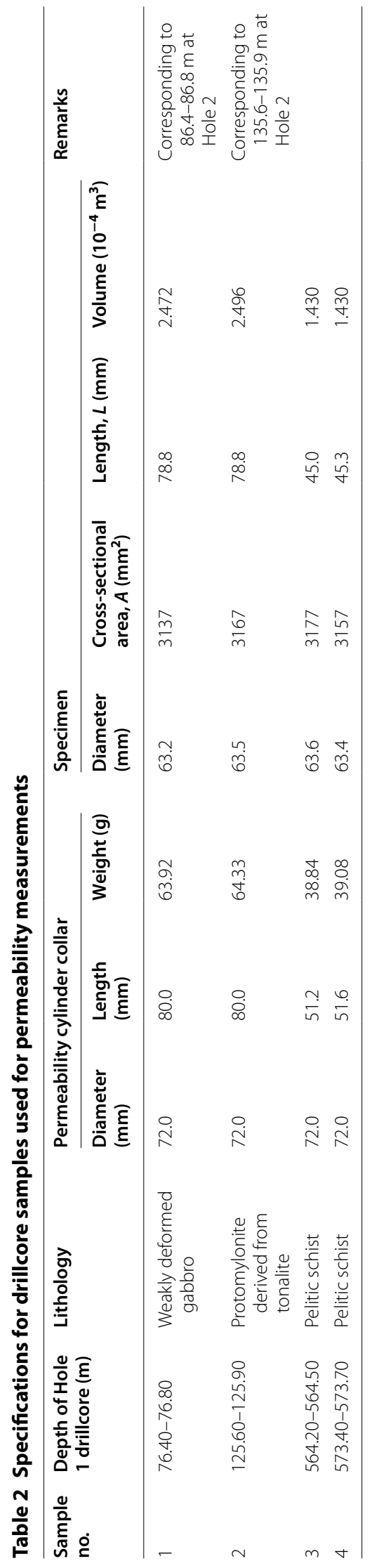


Table 3 Results of the permeability measurements for Samples 1-4

\begin{tabular}{|c|c|c|c|c|c|c|c|c|c|c|}
\hline \multirow[t]{2}{*}{ Number of measurement } & \multicolumn{5}{|c|}{ Sample no. 1 (depth of $76.40-76.80 \mathrm{~m}$ ) } & \multicolumn{5}{|c|}{ Sample no. 2 (depth of $125.60-125.90 \mathrm{~m}$ ) } \\
\hline & 1 & 2 & 3 & 4 & 5 & 1 & 2 & 3 & 4 & 5 \\
\hline Measurement time $\left(t_{2}-t_{1}, s\right)$ & 36,360 & 41,580 & 39,000 & 48,960 & 41,820 & 36,360 & 41,580 & 39,000 & 48,960 & 41,820 \\
\hline Difference of water level $(h, \mathrm{~m})$ & 20.00 & 20.00 & 20.00 & 20.00 & 20.00 & 20.00 & 20.00 & 20.00 & 20.00 & 20.00 \\
\hline Runoff volume $\left(Q, 10^{-7} \mathrm{~m}^{3}\right)$ & 1.0 & 1.0 & 1.0 & 1.0 & 1.0 & 2.0 & 2.0 & 2.0 & 2.0 & 2.0 \\
\hline Hydraulic conductivity $\left(10^{-12} \mathrm{~m} \mathrm{~s}^{-1}\right)$ & 3.5 & 3.0 & 3.2 & 2.6 & 3.0 & 6.8 & 6.0 & 6.4 & 5.1 & 5.9 \\
\hline Permeability $\left(10^{-19} \mathrm{~m}^{2}\right)$ & 3.5 & 3.1 & 3.3 & 2.6 & 3.1 & 7.0 & 6.1 & 6.5 & 5.2 & 6.1 \\
\hline \multirow[t]{3}{*}{ Average permeability $\left(10^{-19} \mathrm{~m}^{2}\right)$} & 3.1 & & & & & 6.2 & & & & \\
\hline & \multicolumn{5}{|c|}{ Sample no. 3 (depth of $564.20-564.50 \mathrm{~m}$ ) } & \multicolumn{5}{|c|}{ Sample no. 4 (depth of $573.40-573.70 \mathrm{~m}$ ) } \\
\hline & 1 & 2 & 3 & 4 & 5 & 1 & 2 & 3 & 4 & 5 \\
\hline Measurement time $\left(t_{2}-t_{1}, s\right)$ & 39,780 & 40,980 & 48,000 & 46,080 & 40,800 & 39,780 & 40,980 & 48,000 & 46,080 & 40,800 \\
\hline Difference of water level $(h, m)$ & 10.00 & 10.00 & 10.00 & 10.00 & 10.00 & 10.00 & 10.00 & 10.00 & 10.00 & 10.00 \\
\hline Runoff volume $\left(Q, 10^{-7} \mathrm{~m}^{3}\right)$ & 1.0 & 1.0 & 1.2 & 1.0 & 0.80 & 1.2 & 1.1 & 1.2 & 1.0 & 0.90 \\
\hline Hydraulic conductivity $\left(10^{-12} \mathrm{~m} \mathrm{~s}^{-1}\right)$ & 3.6 & 3.5 & 3.5 & 3.1 & 2.8 & 4.3 & 3.9 & 3.6 & 3.1 & 3.2 \\
\hline Permeability $\left(10^{-19} \mathrm{~m}^{2}\right)$ & 3.6 & 3.5 & 3.6 & 3.1 & 2.8 & 4.4 & 3.9 & 3.7 & 3.2 & 3.2 \\
\hline Average permeability $\left(10^{-19} \mathrm{~m}^{2}\right)$ & 3.4 & & & & & 3.7 & & & & \\
\hline
\end{tabular}

Permeability was measured five times for each sample

$$
K=\frac{r_{\mathrm{c}}^{2} \ln \left(R_{\mathrm{e}} / r_{\mathrm{w}}\right)}{2 L} \frac{1}{t} \ln \frac{y_{0}}{y_{t}},
$$

where $r_{\mathrm{c}}$ is the casing radius, $r_{\mathrm{w}}$ is the horizontal distance between the well center and original aquifer, $L$ is the length of screen or open section of the well, $y_{0}$ and $y_{t}$ are the vertical distances between the water table at equilibrium and the water level in well at times 0 and $t$, respectively, and $R_{\mathrm{e}}$ is the effective radius defined by Bouwer and Rice (1976). The permeability $k$ was calculated using

$$
k=K \eta /(\rho g)
$$

where $\eta$ is the viscosity of fluid, $\rho$ is the density of the fluid, and $g$ is the acceleration due to gravity. We used $\eta=1.002 \times 10^{-3} \mathrm{~Pa} \cdot \mathrm{s}, \rho=998.2 \mathrm{~kg} \cdot \mathrm{m}^{-3}$ and $g=9.80 \mathrm{~m} \cdot \mathrm{s}^{-2}$.

For both holes, $r_{\mathrm{c}}=0.075 \mathrm{~m}$ and $r_{\mathrm{w}}=0.135 \mathrm{~m}$. For $L$, we used 43.8 and $17.2 \mathrm{~m}$ for Holes 1 and 2, respectively, based on Table 1. Results of slug tests were obtained from spreadsheets from Halford and Kuniansky (2002).

\section{Pumping test}

We analyzed the pumping test data for Hole 2 using the method of Matsumoto and Roeloffs (2003) as follows:

$$
\bar{h}_{\mathrm{w}}(p)=\frac{\left(\frac{Q}{p}\right)\left[F_{1}(p)-r_{\mathrm{w}} S_{\mathrm{w}} F_{2}(p)\right]}{2 \pi r_{\mathrm{w}} T F_{2}(p)-\pi r_{\mathrm{c}}^{2} p F_{1}(p)+\pi r_{\mathrm{c}}^{2} r_{\mathrm{w}} S_{\mathrm{w}} p F_{2}(p)},(4)
$$

where $p$ is the Laplace transform variable, $r_{\mathrm{w}}$ is the radius of the borehole at the screen, $r_{\mathrm{c}}$ is the casing radius, $S_{\mathrm{w}}$ is the skin factor, and $T$ is transmissivity. $F_{1}$ and $F_{2}$ are obtained by

$F_{1}(p)=K_{0}\left[r_{\mathrm{w}}\left(\frac{S p}{T}\right)^{\frac{1}{2}}\right]+2 \sum_{m=1}^{\infty} K_{0}\left[m W\left(\frac{S p}{T}\right)^{\frac{1}{2}}\right]$

and

$$
F_{2}(p)=-\left(\frac{S p}{T}\right)^{\frac{1}{2}} K_{1}\left[r_{\mathrm{W}}\left(\frac{S p}{T}\right)^{\frac{1}{2}}\right],
$$

where $S$ is the storage coefficient, $W$ is the aquifer width, and $K_{0}$ and $K_{1}$ are modified Bessel functions of the second kind and orders 0 and 1 , respectively.

For Hole 2, we applied $r_{\mathrm{c}}=0.075 \mathrm{~m}$ and $r_{\mathrm{w}}=0.135 \mathrm{~m}$, and we assumed no borehole skin effect $\left(S_{\mathrm{w}}=0\right)$ and a broad aquifer $(W=10 \mathrm{~km})$. By applying a typical value of specific storage $S_{\mathrm{s}}$ of unfissured rock $\left(7.46 \times 10^{-7} \mathrm{~m}^{-1}\right.$; Younger 1993) and thickness $b$ of the aquifer $(17.2 \mathrm{~m})$, we assumed $S=S_{\mathrm{s}} \times b \approx 1 \times 10^{-5}$.

\section{Results of hydraulic tests and groundwater pressure observations}

Hole 1

We pumped the groundwater down to $550 \mathrm{~m}$ below ground level to clean the borehole after installation of the casing and before the hydraulic test. We waited to observe recovery of the groundwater level, but it rose only $10 \mathrm{~cm}$ during the following $201 \mathrm{~h}$. After that, we performed six slug tests by filling the borehole with water up 


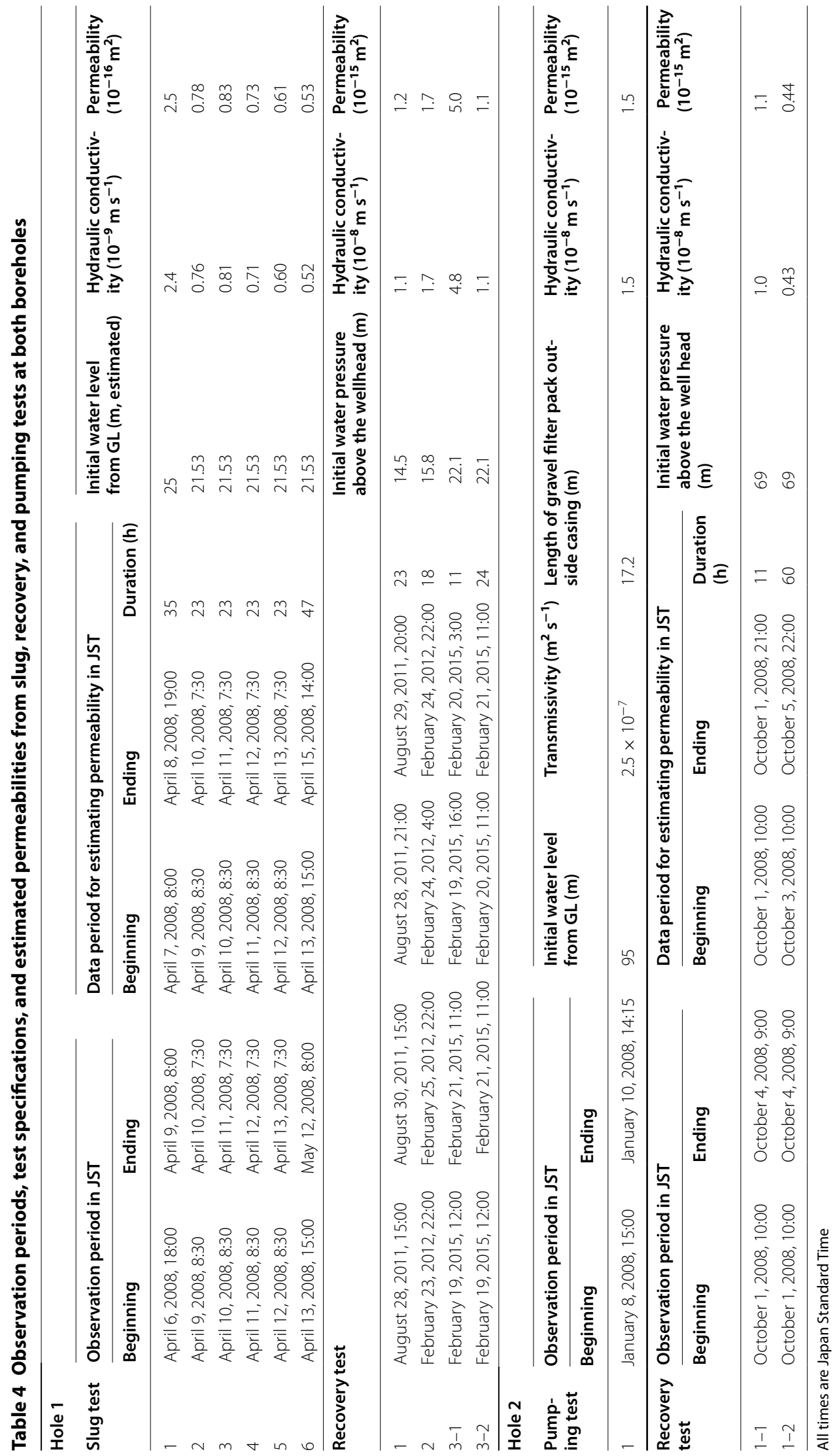


to the wellhead. Table 4 shows the observation periods for the slug tests.

After the slug tests, we started groundwater-level observations at Hole 1 on May 18, 2008. Figure 2 presents long-term groundwater-level observations from May 2008 to December 2016. After we observed an increase in the groundwater level, we closed the Hole 1 wellhead on January 12, 2010, and groundwater level stably rose above the ground level (GL; Fig. 2). Thereafter, we continuously observed increasing groundwater pressure, except when the well was opened for instrument maintenance in August 2011, February 2012, and February 2015 (arrows in Fig. 2). We observed three groundwater pressure recoveries by closing the wellhead after the instrument maintenances and analyzed the three recoveries using Eq. (2) to obtain the permeability. Groundwater pressure had reached $24.3 \mathrm{~m}$ above the ground level as of the end of 2016.

In Fig. 3, we show the results for all nine tests (six slug tests and three recovery tests) as the observed water level with respect to the water table in equilibrium $\left(y / y_{0}\right)$; we have highlighted the slopes used for the permeability estimates. We estimated two slopes for recovery test no. 3 because of the semilogarithmic nature of the water-level curve.

The estimated permeability ranged from $5.3 \times 10^{-17}$ to $2.5 \times 10^{-16} \mathrm{~m}^{2}$ for the six slug tests and from $1.1 \times 10^{-16}$ to $5.0 \times 10^{-16} \mathrm{~m}^{2}$ for the three water-level recoveries (Table 4). Permeabilities estimated with the slug tests were slightly lower than those estimated with the recovery tests.

\section{Hole 2}

We performed a pumping test in January 2008 at Hole 2, with an average pumping rate of $0.46 \mathrm{~L} / \mathrm{min}$. At the start of pumping, the water table was $95 \mathrm{~m}$ deep. The observation period and drawdown graph are shown in Table 4 and Fig. 4, respectively. When we turned off the pump after $88,500 \mathrm{~s}(24.58 \mathrm{~h})$ of pumping, groundwater in the outlet tube below ground level immediately fell down into the well, and we observed an unusual increase in groundwater level at the beginning of the recovery test. We took into consideration this upward shift of groundwater level when we analyzed these pumping test data.

To estimate transmissivity $T$ under the condition $S=1 \times 10^{-5}$, we plotted the theoretical drawdowns of $T=2 \times 10^{-7}, 2.5 \times 10^{-7}$, and $3 \times 10^{-7} \mathrm{~m}^{2} \mathrm{~s}^{-1}$ for comparison with the observed drawdown. As shown in Fig. 4, a transmissivity of $2.5 \times 10^{-7} \mathrm{~m}^{2} \mathrm{~s}^{-1}$ is consistent with the observed drawdown. This transmissivity corresponds to a permeability of $1.5 \times 10^{-15} \mathrm{~m}^{2}$ when we account for the length of the gravel filter pack $(17.2 \mathrm{~m})$.

We closed the wellhead and started observing groundwater pressure in Hole 2 on May 18, 2008. When we closed the wellhead after opening the wellhead one time for maintenance in October 2008, the groundwater pressure recovered (Fig. 5). We also analyzed groundwater pressure recovery using the slug test procedure. As shown in Fig. 4, we used two slopes to determine permeability from the water pressure recovery.

We calculated permeabilities of $4.4 \times 10^{-16}$ and $1.1 \times 10^{-15} \mathrm{~m}^{2}$ for periods $1-1$ and $1-2$, respectively, from the water pressure recovery test in October 2008 (Table 4 and Fig. 4). Thus, our estimate of permeability at

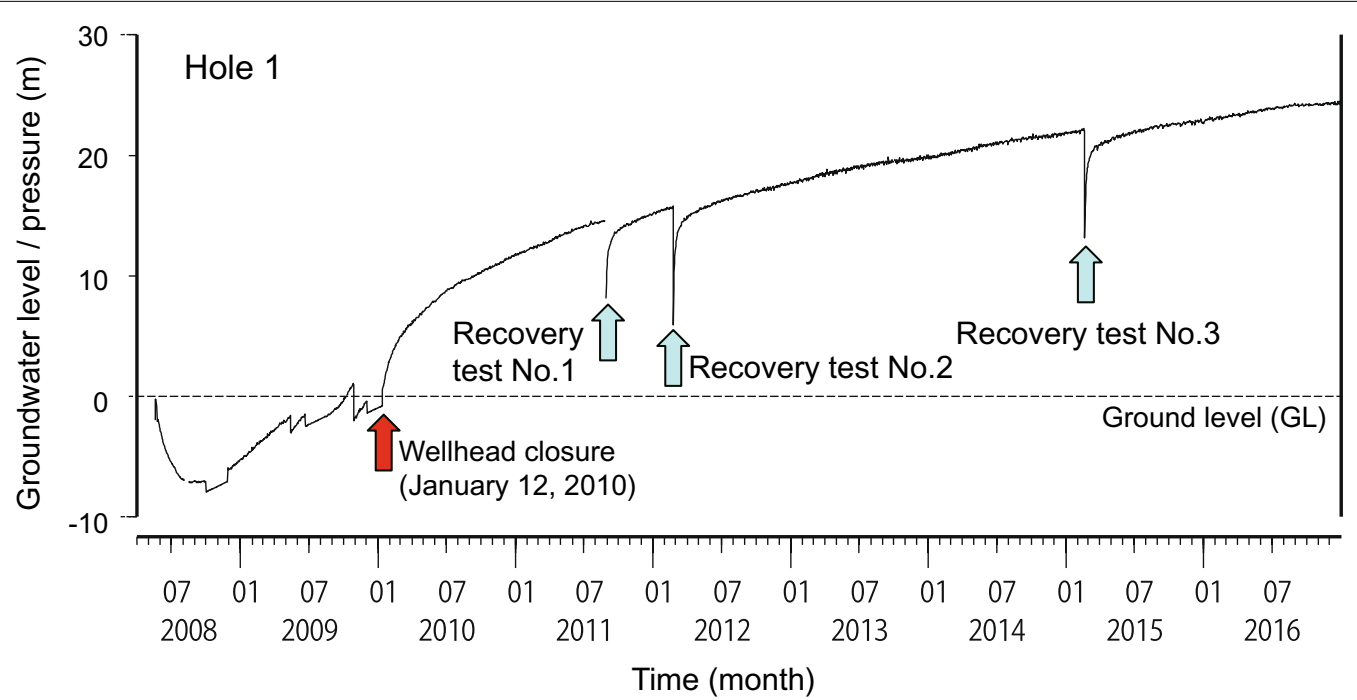

Fig. 2 Daily groundwater-level/pressure data from Hole 1. The red arrow shows when the wellhead was closed to observe groundwater pressure. Blue arrows denote three occasions on which the wellhead was temporarily opened and a recovery test was performed after closure 

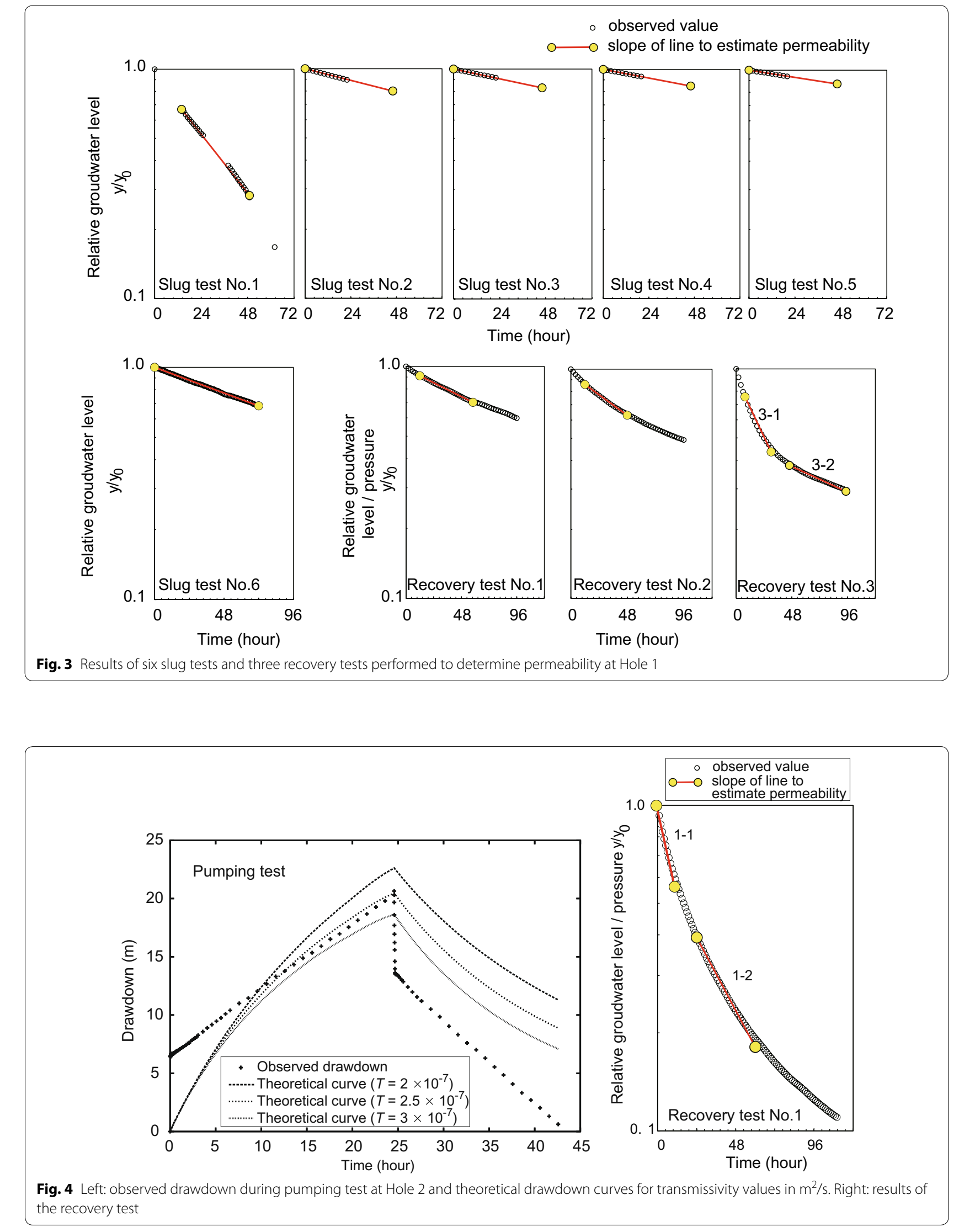


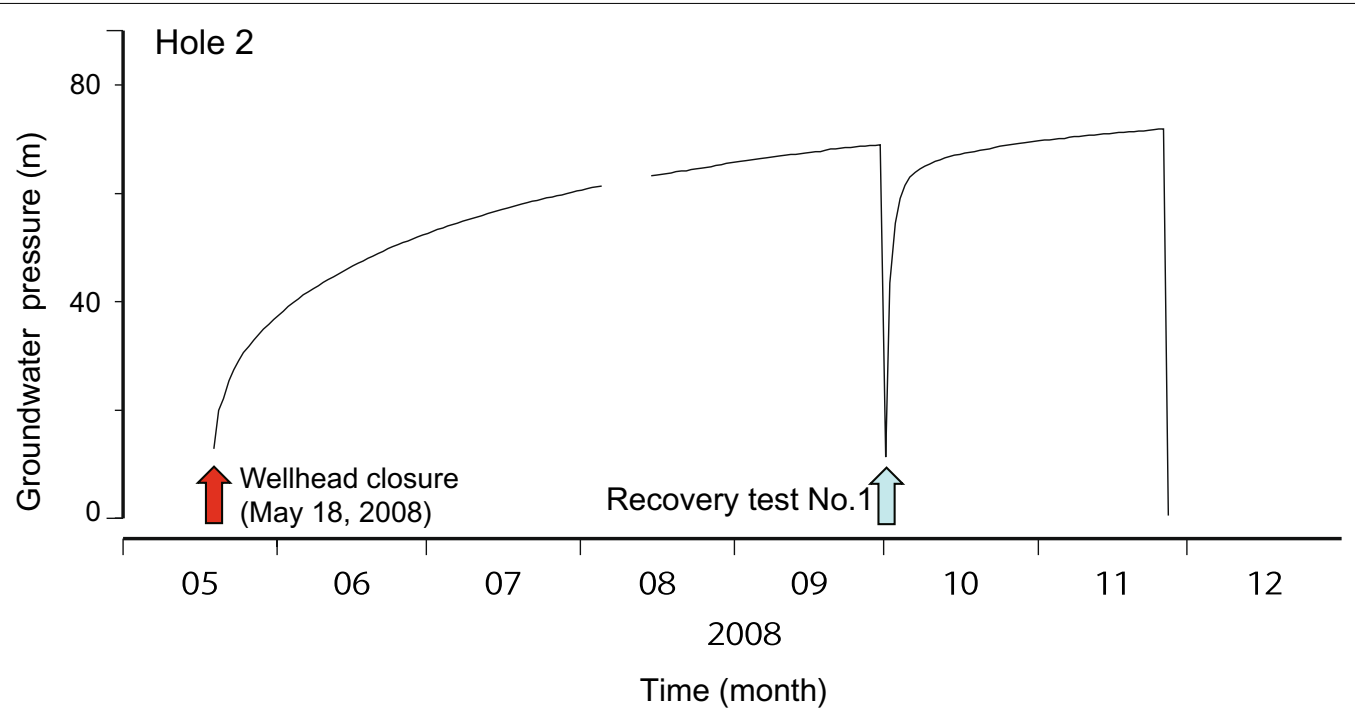

Fig. 5 Daily groundwater pressure data from 2008 at Hole 2. The red arrow shows when the wellhead was closed to observe groundwater pressure. The blue arrow shows when the wellhead was temporarily opened and a recovery test was performed after closure

Table 5 Observation period, data period, and initial water pressure for the trials of permeability estimation using natural recovery of background water pressures in both Holes 1 and 2

\begin{tabular}{|c|c|c|c|c|c|c|c|c|}
\hline \multirow[t]{2}{*}{ Hole } & \multicolumn{2}{|c|}{ Observation period in JST } & \multicolumn{3}{|c|}{$\begin{array}{l}\text { Data period for estimating permeabil- } \\
\text { ity in JST }\end{array}$} & \multirow{2}{*}{$\begin{array}{l}\text { Initial water pressure } \\
\text { above the well head } \\
\text { (m) }\end{array}$} & \multirow[t]{2}{*}{$\begin{array}{l}\text { Hydraulic conduc- } \\
\text { tivity }\left(10^{-11} \mathrm{~m} \mathrm{~s}^{-1}\right)\end{array}$} & \multirow[t]{2}{*}{$\begin{array}{l}\text { Permeability } \\
\left(10^{-18} \mathrm{~m}^{2}\right)\end{array}$} \\
\hline & Beginning & Ending & Beginning & Ending & $\begin{array}{l}\text { Duration } \\
\text { (h) }\end{array}$ & & & \\
\hline \multirow[t]{2}{*}{1} & $\begin{array}{l}\text { January 13, } \\
2010,6: 00\end{array}$ & $\begin{array}{l}\text { January 24, } \\
2017,6: 00\end{array}$ & $\begin{array}{l}\text { May 19, } \\
\text { 2010, 6:00 }\end{array}$ & $\begin{array}{l}\text { April 20, } \\
\text { 2014, 6:00 }\end{array}$ & 34,368 & 24.3883 & 0.42 & 0.43 \\
\hline & $\mathrm{GL}+0.578 \mathrm{~m}$ & $\mathrm{GL}+24.388 \mathrm{~m}$ & & & & & & \\
\hline \multirow[t]{2}{*}{2} & $\begin{array}{l}\text { May } 19,2008, \\
6: 00\end{array}$ & $\begin{array}{l}\text { November 26, } \\
\text { 2008, 6:00 }\end{array}$ & $\begin{array}{l}\text { June } 3,2008 \text {, } \\
\text { 6:00 }\end{array}$ & $\begin{array}{l}\text { August 4, } \\
\text { 2008, 6:00 }\end{array}$ & 1488 & 71.9245 & 7.5 & 7.7 \\
\hline & $\mathrm{GL}+12.826 \mathrm{~m}$ & $\mathrm{GL}+71.925 \mathrm{~m}$ & & & & & & \\
\hline
\end{tabular}

All times are Japan Standard Time

Hole 2 ranges from $4.4 \times 10^{-16}$ to $1.5 \times 10^{-15} \mathrm{~m}^{2}$ based on data from the pumping and water pressure recovery tests.

\section{Discussion}

The background water pressures recovered gradually in both Holes 1 and 2 as shown in Figs. 2 and 5. The recovery rates in the background water pressure were obviously lower than the recovery test shown in "Slug test" section in both holes. We applied Eq. (2) to 47 months recovery of background water pressure in Hole 1 from May 19, 2010, to April 20, 2014, and to 2 months recovery in Hole 2 from June 3, 2008, to August 3, 2008. The results are shown in Table 5 . The estimated permeability in Hole 1 is $4.3 \times 10^{-19} \mathrm{~m}^{2}$ and $7.7 \times 10^{-18} \mathrm{~m}^{2}$ in Hole
2. These estimations are approximate because Eq. (2) is applicable when groundwater pressure/level suddenly decreases in the well (Bouwer and Rice 1976), whereas background water pressure self-recovered gradually by groundwater flowing into the aquifer.

We cannot estimate exact permeability of the aquitard because we need the thickness of aquitard and difference in groundwater pressure between the aquifer and aquitard (Ostendorf et al. 2010). However, the low recovery rates in background water pressure qualitatively show that there is an aquitard or a zone near the aquifer that has a permeability much lower than the in-situ permeability obtained at each borehole (Hole 1: $5.3 \times 10^{-17}$ $5.0 \times 10^{-16} \mathrm{~m}^{2}$, Hole 2: $4.4 \times 10^{-16}-1.5 \times 10^{-15} \mathrm{~m}^{2}$ ). 


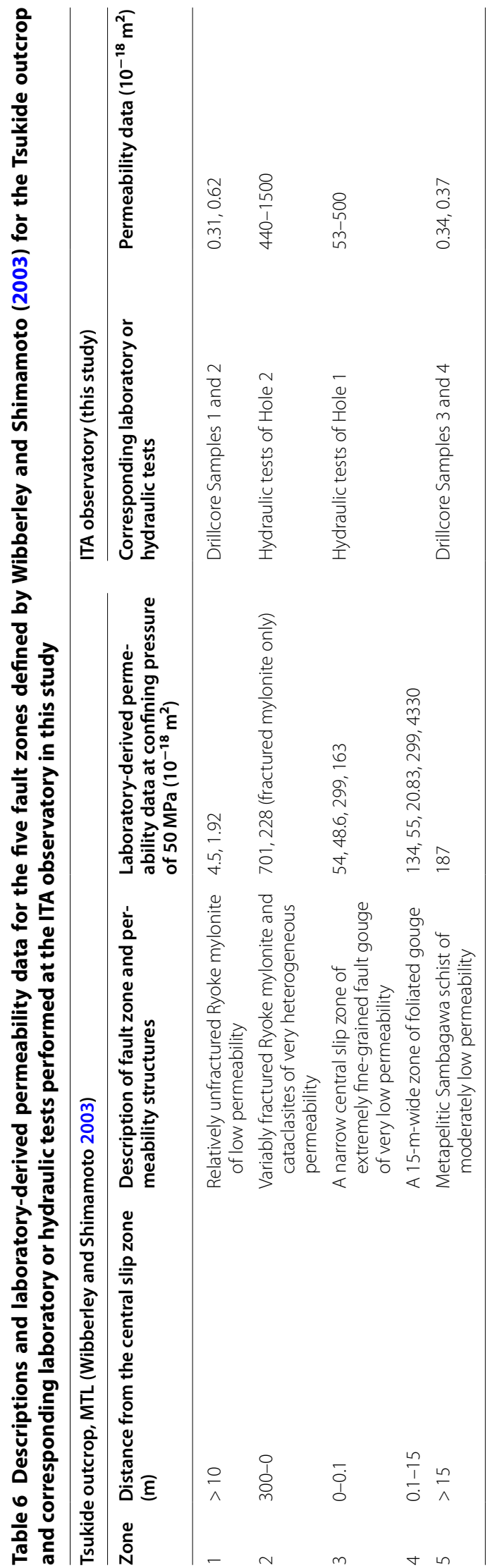


Wibberley and Shimamoto (2003) showed many laboratory-derived permeability data for the MTL fault zone using samples from the Tsukide outcrop. They divided the MTL fault into five zones based on lithology and permeability. The following discussion relates our results to those five zones (Table 6).

The values obtained for drillcore Samples 1 and 2 corresponding to the Hole 2 gravel pack $\left(3.1 \times 10^{-19}\right.$ and $6.2 \times 10^{-19} \mathrm{~m}^{2}$ ) can be compared with Zone 1, relatively unfractured Ryoke mylonite, which has permeability values of $4.5 \times 10^{-18}$ and $1.92 \times 10^{-18} \mathrm{~m}^{2}$ in Wibberley and Shimamoto (2003). The low permeability roughly estimated by recovery of background water pressure in Hole 2 may also be consistent with this zone.

The in-situ values of permeability from one of the branching faults obtained from Hole $2\left(4.4 \times 10^{-16}\right.$ $1.5 \times 10^{-15} \mathrm{~m}^{2}$ ) can be compared with Zone 2, variably fractured mylonite and cataclasite of very heterogeneous permeability, which has permeability values of 2.28 and $7.01 \times 10^{-16} \mathrm{~m}^{2}$ for variably fractured Ryoke mylonite in Wibberley and Shimamoto (2003). Although this zone includes a fault gouge that contains smectite (Tanaka et al. 2012), the in-situ permeability at Hole 2 measures the bulk permeability of both the low-permeability fault gouge and surrounding damage zones.

The gravel filter pack at Hole 1 is located within an area containing damaged schist, fault breccia, and fault gouge derived from the Sambagawa metamorphic rocks (Fig. 1c). The fault gouge in the major strand of the MTL fault zone along Hole 1 corresponds to Zone 3, a narrow central slip zone of extremely fine-grained fault gouge of very low permeability, and the damaged schist and fault breccia correspond to Zone 4, where fracturing and cataclasis occurred in the Sambagawa metamorphic rocks and the grain size increases with distance from the center of the fault zone. Thus, the values for permeability obtained from the major strand in Hole $1\left(5.3 \times 10^{-17}\right.$ $5.0 \times 10^{-16} \mathrm{~m}^{2}$ ) correspond to those for the bulk permeability of Zones 3 and 4 .

The values obtained from protolith Samples 3 and 4 corresponding to Hole $1\left(3.4 \times 10^{-19}\right.$ and $3.7 \times 10^{-19}$ $\mathrm{m}^{2}$ ) can be compared with Zone 5, Sambagawa schist of moderately low permeability, which has a permeability of $1.87 \times 10^{-16} \mathrm{~m}^{2}$ in Wibberley and Shimamoto (2003), although the Hole 1 samples had much lower permeability.

The low permeability roughly estimated by the recovery in background water pressure in Hole 1 may be compared with either a narrow central slip zone of extremely fine-grained fault gouge of very low permeability in Zone 3 located beyond the aquifer of Hole 1, or the Sambagawa schist of moderately low permeability in Zone 5 underneath the aquifer of Hole 1.
Thus, our results from the ITA observatory reflect the permeability properties of the MTL fault zone derived from laboratory data by Wibberley and Shimamoto (2003).

\section{Conclusions}

We performed hydraulic tests and long-term groundwater-level observations at Holes 1 and 2 drilled into a major strand of the MTL fault zone and one of the branching faults in the hanging wall of the MTL, respectively. The estimated permeabilities ranged from $5.3 \times 10^{-17}$ to $5.0 \times 10^{-16} \mathrm{~m}^{2}$ and $4.4 \times 10^{-16}$ to $1.5 \times 10^{-15} \mathrm{~m}^{2}$ at Holes 1 and 2, respectively. Recovery rates of long-term background water level in Holes 1 and 2 suggest the presence of zone adjacent to the aquifer with lower permeability than that estimated by the hydraulic tests. The bulk permeability values we obtained were similar to those obtained from MTL outcrop samples by Wibberley and Shimamoto (2003). The variability in permeability found in this study reflects the complex structure of the MTL fault zone.

\section{Abbreviations}

ITA: Matsusaka-litaka (observatory); MTL: Median Tectonic Line (fault zone).

\section{Authors' contributions}

NM analyzed the hydraulic tests and wrote the manuscript except for the lithologic explanation. NS prepared the ITA observatory drilling plan and wrote the lithology explanation. Both authors read and approved the final manuscript.

\section{Acknowledgements \\ N. Koizumi provided us the opportunity to measure in-situ permeability at the ITA observatory. Y. Kitagawa, S. Itaba, M. Takahashi, T. Sato, N. Takeda, and T. Ookawa contributed to the long-term observation of groundwater level/ pressure at the ITA observatory. Discussions with R. Sutherland were insightful. Nissaku Co. Ltd. performed hydraulic tests and measured the permeability of drillcore samples as a part of construction of the ITA observatory. We thank the two anonymous reviewers whose comments helped improve and clarify this manuscript.}

\section{Competing interests}

The authors declare that they have no competing interests.

\section{Ethics approval and consent to participate}

This study does not require ethical approval.

\section{Funding}

The Matsusaka-litaka observatory was constructed by the grant-in-aid of facilities expense by Ministry of Economy, Trade and Industry (METI). This work was partly supported by MEXT KAKENHI (Grant Nos. 26109004 and 26109006) and JSPS and RSNZ under the Japan-New Zealand Research Cooperative Program.

\section{Publisher's Note}

Springer Nature remains neutral with regard to jurisdictional claims in published maps and institutional affiliations.

Received: 31 March 2017 Accepted: 19 December 2017

Published online: 25 January 2018 


\section{References}

Bense VF, Gleeson T, Loveless SE, Bour O, Scibek J (2013) Fault zone hydrogeology. Earth Sci Rev 127:171-192. https://doi.org/10.1016/j. earscirev.2013.09.008

Bouwer H (1989) The Bouwer and Rice slug test - an update. Ground Water 27:304-309. https://doi.org/10.1111/j.1745-6584.1989.tb00453.x

Bouwer H, Rice RC (1976) A slug test for determining hydraulic conductivity of unconfined aquifers with completely or partially penetrating wells. Water Resour Res 12:423-428. https://doi.org/10.1029/WR012i003p00423

Caine JS, Evans JP, Forster CB (1996) Fault zone architecture and permeability structure. Geology 24(11):1025. https://doi. org/10.1130/0091-7613(1996)024<1025:fzaaps>2.3.co;2

Carpenter BM, Kitajima H, Sutherland R, Townend J, Toy VG, Saffer DM (2014) Hydraulic and acoustic properties of the active Alpine Fault, New Zealand: laboratory measurements on DFDP-1 drill core. Earth Planet Sci Lett 390:45-51. https://doi.org/10.1016/j.epsl.2013.12.023

Faulkner DR, Jackson CAL, Lunn RJ, Schlische RW, Shipton ZK, Wibberley CAJ, Withjack MO (2010) A review of recent developments concerning the structure, mechanics and fluid flow properties of fault zones. J Struct Geol 32:1557-1575. https://doi.org/10.1016/j.jsg.2010.06.009

Halford KJ, Kuniansky EL (2002) Documentation of spreadsheets for the analysis of aquifer-test and slug-test data, U.S. Geological Survey Open-File Report, 02-197

Itaba S, Koizumi N, Matsumoto N, Ohtani R (2010) Continuous observation of groundwater and crustal deformation for forecasting Tonankai and Nankai earthquakes in Japan. Pure appl Geophys 167:1105-1114. https:// doi.org/10.1007/s00024-010-0095-z

Japanese Geotechnical Society (2015) Japanese Geotechnical Society Standards - laboratory testing standards of geomaterials. Maruzen Publishing Co., Ltd., Tokyo

Kitagawa Y, Kano Y (2016) Changes in permeability of the Nojima fault damage zone inferred from repeated water injection experiments. Earth Planets Space 68:185. https://doi.org/10.1186/s40623-016-0566-2

Kitagawa Y, Koizumi N, Notsu K, Igarashi G (1999) Water injection experiments and discharge changes at the Nojima fault in Awaji Island, Japan. Geophys Res Lett 26:3173-3176. https://doi.org/10.1029/1998gl005263

Kitagawa Y, Fujimori K, Koizumi N (2002) Temporal change in permeability of the rock estimated from repeated water injection experiments nea the Nojima fault in Awaji Island, Japan. Geophys Res Lett. https://doi. org/10.1029/2001gl014030
Kitagawa Y, Fujimori K, Koizumi N (2007) Temporal change in permeability of the Nojima fault zone by repeated water injection experiments. Tectonophysics 443:183-192. https://doi.org/10.1016/j.tecto.2007.01.012

Koizumi N (2013) Earthquake prediction research based on observation of groundwater-earthquake forecasting based on crustal deformation estimated from groundwater level change. Synthesiology 6:27-37

\section{(English edition)}

Matsumoto N, Roeloffs EA (2003) Hydrological response to earthquakes in the Haibara well, central Japan-II. Possible mechanism inferred from time-varying hydraulic properties. Geophys J Int 155:899-913. https://doi. org/10.1111/j.1365-246X.2003.02104.X

Ostendorf DW, DeGroot DJ, Judge Al, LaMesa DF (2010) Method to characterize aquitards above leaky aquifers with water supply wells. Hydrogeol J 18:595-605. https://doi.org/10.1007/s10040-009-0563-7

Shigematsu N, Fujimoto K, Tanaka N, Furuya N, Mori H, Wallis S (2012) Internal structure of the Median Tectonic Line fault zone, SW Japan, revealed by borehole analysis. Tectonophysics 532-535:103-118. https://doi. org/10.1016/j.tecto.2012.01.024

Sutherland R, Toy VG, Townend J, Cox SC, Eccles JD, Faulkner DR, Prior DJ, Norris RJ, Mariani E, Boulton C, Carpenter BM, Menzies CD, Little TA, Hasting M, De Pascale GP, Langridge RM, Scott HR, Lindroos ZR, Fleming B, Kopf AJ (2012) Drilling reveals fluid control on architecture and rupture of the Alpine fault, New Zealand. Geology 40:1143-1146. https://doi. org/10.1130/g33614.1

Tanaka N, Furuya N, Fujimoto K, Shigematsu N (2012) X-ray diffraction analysis on the samples of the borehole core penetrating the Median Tectonic Line, the eastern Kii Peninsula, SW Japan. Bull Tokyo Gakugei Univ Div Nat Sci 64:77-128

Wibberley CAJ, Shimamoto T (2003) Internal structure and permeability of major strike-slip fault zones: the Median Tectonic Line in Mie Prefecture, Southwest Japan. J Struct Geol 25:59-78. https://doi.org/10.1016/ s0191-8141(02)00014-7

Xue L, Li HB, Brodsky EE, Xu ZQ, Kano Y, Wang H, Mori JJ, Si JL, Pei JL, Zhang W, Yang G, Sun ZM, Huang Y (2013) Continuous permeability measurements record healing inside the Wenchuan earthquake fault zone. Science 340:1555-1559. https://doi.org/10.1126/science.1237237

Younger PL (1993) Simple generalized methods for estimating aquifer storage parameters. Q J Eng GeolHydrogeol 26:127-135. https://doi.org/10.1144/ gsl.qjeg.1993.026.02.04

\section{Submit your manuscript to a SpringerOpen ${ }^{\circ}$ journal and benefit from:}

- Convenient online submission

- Rigorous peer review

- Open access: articles freely available online

- High visibility within the field

Retaining the copyright to your article

Submit your next manuscript at $\boldsymbol{~ s p r i n g e r o p e n . c o m ~}$ 